\title{
Transformative sense-making: Development in whose image? Keyan Tomaselli and the semiotics of visual representation
}

\author{
John J. Williams
}

\section{Introducing the problematique of sense-making}

The defining and distinguishing feature of Homo sapiens is its ability to make sense of the world, i.e. to use its intellect to understand and change both itself and the world of which it is an integral part. It is against this backdrop that this essay reviews Tomaselli's 1996 text, Appropriating Images: The Semiotics of Visual Representation, 1 by summarizing his key perspectives, clarifying his major operational concepts and citing particular portions from his work in support of specific perspectives on sense-making. Subsequently, this essay employs his techniques of sense-making to interrogate the notion of "development". This exercise examines and confirms two interrelated hypotheses: first, a semiotic analysis of the privileged notion of "development" demonstrates its metaphysical/ideological, and thus limiting, nature especially vis-a-vis the marginalized, excluded, and the collective Other, the so-called Developing Countries. Second, the interrogative nature of semiotics allows for an alternative reading and application of human potential or skills in the quest of a more humane social and global order, high- lighting thereby the transformative implications of a reflexive epistemology. Apart from the foregoing introductory observations, the remainder of this essay focuses on: Tomaselli's methodology-his textually and empirically engaged presence; transdisciplinary sense-making: a sine qua non for transforming unequal relations of power; the semiotics of development-in whose image? Here it is suggested that development, as a historically driven, materially grounded, multi-dimensional process, is characterized by systemic contradictions, structural tensions and conjunctural strugglesideologically, economically, politically, and so forth. This section is followed by an exploration of transdisciplinary sense- making to transform the human condition. Since sense-making is the focus of this essay, it concludes with an analysis of two previous reviews of Tomaselli's text. Accordingly, the rubric is entitled "Making sense of Tomaselli". It accents the highly selective reading/misreading of his work. Thus the need to indicate both the historical-materialist substance and elucidatory nature of his work vis-à-vis unequal relations of power across and within most societal sectors. This essay, as indicated above, commences with a consideration of research methodology as a basis for understanding his Appropriating Images: The Semiotics of Visual Representation.

\section{Tomaselll's methodology: an engaged presence}

Since Tomaselli's text is an application of Charles Sander Peirce's notion of pragmatism in the domain of semiotics it is necessary to locate the latter's work within the realm of epistemology. In his article "How to Make our Ideas Clear" [1878], Peirce introduces the 
law of Pragmatism, viz: the value of an idea lies in its practical application. Pierce worked out an objective-idealist theory of development which posits that "chance" and "love" are the determining force of human progress [International Publishers 1984: 312]. In his text, Tomaselli embraces Peirce's call for the practical application of ideas by positioning himself both existentially (i.e. through his struggle against apartheid in South Africa) and theoretically (through a historical materialist critique of extant concepts and theories on sense- making) as an engaged and reflecting author/activist.

In the "Foreword" [1996: xi] to this text Richard Chalfen of the Center for Visual Anthropology, Temple University, writes: "Disciplinary texts can be understood as constructions of knowledge about previous constructions of knowledge". Indeed, throughout his text, Tomaselli is present as "theoretician, practitioner and observer" [xiii] of the subject matter and by contextualizing his presentations through "interpretation, decoding, viewing and understanding ...the ways viewers 'read' or actively make meaning in culturally realised con-text" [xiv].

By exploring "[h]ow, when, where and under what circumstances is meaning made meaningful" [xv], his text acquires and exudes historical depth, sensitivity, and is presented in an informed, direct and uncompromising way [xvi].

It is in such an engaged, "theoretically-grounded presence", that Tomaselli focuses on semiotics-the study of how meaning is made [2]. For Tomaselli, semiotics is not a scholastic exercise, a free-floating disciplinary signifier in academic space. On the contrary, for him, semiotics is fundamentally about making sense of real humans in space and time--ontologically, epistemologically, hermeneutically and thus historically. For example, quite early in his text, Tomaselli indicates how films on Africans (the dark Other), are often "patronising", and are frequently designed to ensure "labour docility, distracting entertainment and subordination and/or consumption on the dark continent" $£ 5$-6]. This empirically-engaged presence raises for Tomaselli the cardinal question: "how do different groups and constituencies make sense of the images of the Other? [and how] do Others make sense of themselves? 2 How does one explain these different forms/types of sense-making?" [6]. His text accordingly highlights the inability of the West to listen to the voices of the Other-a central theme of his study [7].

Having framed the problematique of making sense of the "Other" as a salient issue for the "West", Tomaselli [7] points out that ethnographic studies became increasingly the conduit to document and relay truth-claims about the Other. Equally important though, he also indicates that (in the wake of formal independence from the colonial power) systematic ethnographic studies became a State pursuit in developing countries [7]. In this regard, the author describes the role of the Indian Ministry of Information and Broadcasting, the Institute of Nationality Studies in China, the efforts of the Japanese, Nordic countries and Australia in constructing or documenting specific ethnographic profiles of indigenous people [7-9]. These ethnographic films were increasingly liberatory in form and substance. For example, the Australian Institute of Aboriginal Studies, established in 1961, in the 1980 s dealt with issues such as land rights, race relations, political rights and ill-treatment. In Tomaselli's assessment these films showed a "sense of urgency, confronting political controversy, white myths about aboriginals and dispossession of indigenous groups" [9]. 
Having perused a section of established scholarship on the Other, often pre- sented in autobiographical format and couched in the semantics of a pervasive solipsism, Tomaselli [17] describes the purpose of anthropology thus: "Anthropology perhaps seeks to discover the collective or cultural unconscious of its own societies. It attempts this by reconstructing the internalised, repressed Other that is still thought to manifest fragmented aspects of itself in safely distant pre- scientific, pre-modern cultures". Even so, this appropriation of anthropology as a potentially liberatory endeavor is not unproblematic, since, in the era of postmodernism, images and image-making of the Other are readily being commodified, packaged, and circulated as "representing the primordial Other" as a romanticized artifact, frozen in time and space, to be consumed by the global tourist in the quest of an elusive/illusive, nostalgic past. Hence the omnipresent postmodernist gaze upon the so-called developing countries not so much as an existential, geo- graphical, spatial nexus, an index of human suffering and potential, but rather as an image of Nature "outside" the "civilizing" culture of the Occident. Thus the othering, labelling of those humans inforeign lands as less developed, uncultured, unsophisticated, even uncivilized! In this regard, Tomaselli's characterization of consumerism in the postmodernist era is quite striking when he observes:

The impulses of modernism and post-modernism are transported to the Third and Fourth Worlds by anthropologists, travellers, tourists, film-makers and advertisers, development projects, capital and the global mass media. 'Indigenous' groups, generally affirmatively imaged anthropological subjects in the modem era, become decentred and irrelevant, deauthored anthropological objects for consumption in the post-modem era. They are at the mercy of a new form of mass-mediated, confetti-like, post-scientific gaze, entertainment for post-industrial readers and audiences. [18; original emphasis]

Tomaselli's interrogation of the postmodernist "othering", of indigenous culture and cultural practices, as a profitable commodity on the tourist market, has pro- found structural and ideological significance for the sociocultural policies and practices in South Africa, especially in relation to the authenticity and inclusive- ness of the historical artifacts, records and related archival material displayed and contained in its museums. It is precisely the continuities, in a postapartheid South Africa, of "othering" as an existential negative in the images,symbols, and museum records of "indigenous" people and their culture that inform the current debate, in South Africa, on the need to confront, in the words of the journalist Mxolisi Mgxashe, the "lack of change and Eurocentrism in South Africa's museums"

[Cape Times, 15 March 2000]. Reports Mgxashe, in this regard, "RACISM and Eurocentric collections-the continued display of statues made from casts taken from live Khoisan men 'among animals, whales and dinosaurs'-is at the heart of grievances raised by black museum workers in the Western Cape who have called for a complete overhaul of museums". Based on information provided by Colin Jones, who has been appointed to oversee the transformation of museums in the Western Cape, Mgxashe writes:

[T] he transformation of those institutions still living inthe past had already begun with the amalgamation of the cultural and history museums, the South African Museum, the South African National Gallery, Michaelis Collection, William Fehr Collection, and the 
satellite museums into one administration under the South African Flagship Institute [SFI].

Quoting Jones, Mgxashe states:

The challenge facing the SFI is enormous. It is challenged both to undo the apartheid legacy and to create an institution that is truly African and world class. This is fundamental to President Thabo Mbeki's vision of an African Renaissance. [The challenge is also] to move the museums away from the culture of over-dependence on state funding, to a new culture that would have strong commercial leanings for greater self-sufficiency and creativity.

It is precisely the latter part of Jones's envisaged changes vis-a-vis the South African museums that validates Tomaselli's perspectives on the "marketized" role of culture and cultural artifacts in a post-modernist era [cf. Waugh 1992]. And it is precisely the increasing "commodification" of archival records, historical images, symbols and representations in an overly carnivalesque manner and as a "tourist-package"-a gaze at the "South African People" in the totality of their idiosyncrasies, particularities and differentiated sub-formations-that profoundly problematizes the form, substance and dimensions of the symbol, image and representations of human development on the African subcontinent [cf. Mamdani 1996].

Complicating visual representation even more is the transdisciplinary nature of social problems, i.e. social problems are structurally, organically and thus ontolo- gically interrelated and do not occur within the confines of neatly delineated disciplinary boundaries [cf. Capra 1997]. In like manner values, norms, codes/ principles of judgement or conduct are not frozen in time and space but are subject to historicallydriven processes of contradiction, tension, conflict, struggles and change [Harvey 1989]. This means, amongst other things, as Tomaselli accents throughout his text, that humans themselves are historical/ cultural beings where language itself experiences syntactical, semantic and pragmatic changes whilst the etymological variants assume new forms of application, interpretation and thus situated relevance [cf. Eco 1979; Griswold 1994]. Accordingly, in the argot of the illustrious liberation theologian, Leonardo Boff 3 [1988: 31]: "it is no longer tenable even plausible simply endorsing, in both substance and form, what has been inherited from the past. Indeed, nothing is worthwhile until it is tried and criticized. In principle nothing is immutable. Everything is open-ended." This means by endorsing this flexible, open-ended methodology towards social reality, that it is possible, by another route, to look at sense-making without privileging/ deprivileging any specific hermeneutic framework (of reference). What especially has to be appreciated, in this regard, is that "[l]anguage is not the original reality.

It is a translation, an interpretation, a second stage" [Boff 1988: 35). Wholeness, completeness, totality is the original reality beyond the capacity of language as container/receptacle of its multi-dimensionality [cf. Eco 1979). History, in its triadic, linear/temporal form, of past, present and future, represents at best an approximation of this experiential/ontological process-driven reality [cf. Hobsbawrn 1997). Sense-making, in its temporality, is thus grounded within, and derives, however partially, from the multilayered processes informing the human condition [cf. Young 1995). Sense-making, as a 
historically-informed process, is thus, as Boff [1988: 36) accents, about humanity as "existence, situation, decision-making, and commitment. It is human beings defining themselves by living in the world with others in society and thus fashioning their identity. Itis when human beings thoroughly live their historicity, open out to the world and others, and commit themselves to the process of liberation, that they begin to glimpse what they really are"-a thinking, creative, sense-making presence in time and space. This means that, cognitively, perceptually, and experientially, human beings are beings inextricably linked to one another as they produce and appreciate specific meanings in their individual and collective lives. These relationships are, how- ever, subject to manipulation and reinforcement and signify immanence, i.e. social relations of control/power/subordination are existentially, ontologically, intrinsically, inherently and inalienably present. Conjuncturally and organically, though, immanence is linked to differentiating contradictions, tensions, struggles, change and transformation. This means human beings can rise infinitely above the situation in which they find themselves. This change-inducing, transformative sense-making experience is called transcendence, i.e. overcoming, unequal/ oppressive relations of power. Indialectical materialist terms, human beings thus "appear as beings who are immanent and transcendent, already fashioned and still in the making, established through the past into the present, yet open toward an unknown future". This is the pristine human reality in the specificity of the temporal/spatial matrix of contestatory relations of power. Thus the historical materialist nexus of space and time accents both interiority and exteriority of the human condition and constitutes sense-making of the most transformative kind. Thus far it has been suggested that sense-making comes through human experience, encounters, interactive relations whether dialogical or monological, whether democratic or autocratic, whether consensual or coercive. With the view to clarify and grasp the originary nature of sensemaking, it still has to be mentioned that [h] uman beings gain experience insofar as they go out of themselves, confront inner and outer realities, meet others, endure dangers and trials, set out on a journey, and find their way to get through. This is the drama of human life itself since it is never given ready-made. Life must be put together, a road must be found, some meaningful way through must be discovered. In so doing, human beings will have to make attempts and overcome trials. Experienced human beings are people who have passed through trials and sufferings, who have plunged into life and its dangers, and who have learned from all that. Their knowledge is not book knowledge; it is knowledge they earned with their own sweat and blood.

[Baff 1988: 39]

And, as Boff [1988: 39] accents, direct experience provides us with a kind of knowledge that cannot be mediated only through rational argumentation as it has a unique "taste and flavor", the "result of many trials and encounters".

Even so, as Boff [1988: 40] makes clear:

[E]xperience is not only scientia, a kind of knowledge. It is also an authentic scientia, a kind of awareness. Ingoing out of self and approaching the world, human beings bring all that they are with them: their a priori categories, their own experiences, and their historico- cultural heritage. The world reveals itself to human awareness in accordance with the structural norms governing that awareness. Experience is never without certain presuppositions. Itis always given direction by some prior model, which is then tested in 
the critical confrontation with reality in order to be confirmed, corrected, improved, or rejected. Experience arises in the encounter between the world and consciousness. Itis structured as history, as the journey of a given individual or a given human group.

This means the world is not a mythical reality nor is it a self-sustaining meta- physical entity, frozen in time and space. On the contrary, human experience suggests it is a historical reality that has grown out of the past, is embedded in the present and still moving towards some unknown, open-ended future. And even though we approach the world in scientific and technological terms, study its inner laws and grasp it in dialectical terms and explain it rationally, this "modem" approach stands among older ways that still persist in many sections of society on both the individual and collective level of human consciousness. Indeed, as Boff [1988: 40, 52-53] stresses: "science has not obliterated the older realms of myth and metaphysics. It is an extension of them insofar as it moves beyond them through dialectical interplay." Thus, methodologically and ontologically, both the rational and irrational, the conscious and unconsciousness, the oral and the literary traditions, constitute the richly-textured, multi-faceted epistemological basis of sense-making. Approaching sense-making within such an all-embracing analytical framework has a number of interrelated methodological and hermeneutic consequences for disclosing and understanding the condition humaine, viz:

First, "[d]irect access to reality, without passing through a subject, is impossible because it is the concrete subject, with specific conditionings, possibilities and limitations, that goes to the object" [Boff 1987:41]. Thus sense-making will always mean interpretation. Only one who interprets would construct sense/meaning [cf. also Eco 1979].

Second, sense-making does not mean merely understanding ancient (doctrinal) texts; it also means comprehending all manifestations of life and knowing how to relate them to one another, especially in matters concerning not only the individual but also the collective universality of people as expressed by issues such as development, justice and democracy [Boff 1987: 41].

Third, "[t]he human person is essentially a being on the road to itself. People seek to realize themselves on all levels: in body, soul, and spirit; in biological, spiritual and cultural life. But this desire is continuously obstructed by frustration, suffering; the absence of love, and the lack of unity with self and others"[Boff 1987: 134].

Fourth, "[h]uman existence has meaning only if understood as a total opening of oneself, as a focal point of relationships branching out in all directions to the world. The more human beings relate to others and go out of themselves, the more they grow and become human" [Boff 1987:197].

Fifth, myth is the form whereby the collective unconscious represents for itself the radical meaning of seemingly permanent situations in life such as categorical relations of powerdeveloped /underdeveloped, rich/poor, white/ black, male/female, employer/employee. This means, amongst other things, "myth possesses a language, a logic, and structures of its own". Making sense of extant, operational myths thus implies the hermeneutic process of demythologization. "Demythologization, however, does not mean confronting a specific 
myth with objective reality", which would not mean comprehending it. On the contrary, it means interpreting, explaining the myth "as the language of the unconscious", accepting it as a legitimate form of "logical comprehension", and integrating it in the process of making sense of the human condition [Boff 1987:23].

Having provided methodological and hermeneutic support for the Tomasellian radicalization and demythologization of sense-making, it should be readily clear that, generally, visual images transmit/ elicit/ constitute information about "pat- terns of dominance and rupture" [Tomaselli 1996: 20]. In this regard, Tomaselli deems it apposite to make a distinction between semiology and semiotics. Semiology excludes .experience as a defining, constitutive, methodological and substantive component of human inquiry, whilst semiotics is a historically- driven index of human relationships and progress through time and space [21-22]. Informed by the preceding historical materialist approach to semiotics, Tomaselli sets himself a threefold task, viz: first, to construct a semiotic method to study visual anthropology and sociology; second, to reconceptualize visual anthropology and to link this reconceptualization to the centering of the Other in tracking its extant theoretical perspectives; and third, to subject film theory, on the basis of various case studies, to a semiotically oriented, historically-informed inquiry Icritique with the view to disclose and transform dominant discursive signifiers and resultant relations of power within and across various disciplines aligned to visual anthropology [23-25].

In this section it has been suggested, amongst other things, that dominant [dis]empowering discourses are often based on myths either reinforcing or contesting existing relations of power. In Tomaselli's text [66] myths are "recur- ring themes, icons and stereotypes which claim common recognition within a cultural group with a shared ideology". Based on colonial-cum-apartheid forms of racial oppression and economic exploitation in South Africa, he indicates, "[m]yths transform history into nature: dominant historical processes are made to appear 'natural' and 'inevitable' even 'Godgiven"'. In his view "it is myths spoken from the seats of power whose objective is the maintenance of power, which become the public myths" [70-73]. Since seats of power are structurally and organically differentiated and are often all-embracing, Tomaselli's approach to sense-making assumes a transdiciplinary focus in relation to the construction, communication and dissemination of images vis-a-vis the human condition.

\section{Transdisci plinary sense-making: a sine qua non for transforming unequal relations of power}

It can be suggested that, for Tomaselli (1996: 142], "transdisciplinary sense- making acknowledges that ontological relativity exists in any encounter between ["developed" and "developing"] societies, a causal factor in the incapacity of, for example, development agencies to apply their projects successfully". This is so as "meanings [of development] are observed and documented, and threaded through different kinds of sign [image] systems. Losses, misunderstandings and distortions occur at every point in such crosscultural translations" [Tomaselli 1996: 138]. Hence the import of epistemological reflexivity which "should provide an ethical framework", a methodology, that does not 
conceal, for example, the dominant dass relations and traumatic experiences associated with the creation of impoverished townships (ghettos) in South Africa [Tomaselli 1996: 215]. For Tomaselli [1996: 265-279], such an ethical framework, informed by transdisciplinary sense-making, accents self-criticism, open-endedness, the import of oral histories (subjugated knowledges), prevailing preconceptions in structuring and implementing specific development programs, dialogical engagement/ cross- boundary learning, not monological dictation and unilateral prescriptions, with the view to reconfigure, realign and transform the dominant relations of power and practices in society. Praxiologically and deontologically, this multi-levelled process of transdisciplinary sense-making constitutes the demythologization, radicalization and authentication of human development, in the image of those who "have to continue their lives where they are", whilst we, the sense-makers, from the outside, "can take our gear and go home" [Tomaselli 1996: 279].

Yet, as Tomaselli [156-159] points out, it is not merely myths which reinforce existing relations of power. Technology plays an equally important role in determining/reinforcing dominant relations of power. In this regard Tomaselli [156] avers: "[A]ll cinematic expression, interpret 'reality' through the processes and codes of camera optics, framing, editing, chemical treatment, and very often, the postsynchronization of sound effects and music. Overlaid on these influences are the productive forces and ideology of the film-makers themselves".

Accenting the reifying role of technology in capturing, communicating, disseminating specific images of humankind, Tomaselli [156-57] observes:

Since media are technological, a product of industrial relations of production, it follows that technology is implicated in media construction of reality. It has its own built-in ideological and semiotic dynamics. Perspective, angles, zoom, colour, screen ratios, are some of these. Only certain kinds of technology thought to have immediate profit-taking capacity are developed. In the case of the media, this technology ranks and naturalizes certain forms of expression over others. As the centralization of capital occurs, so it is the owners of technology who increasingly come to determine not only the manufacture of hardware and installation of systems, but also the development of programmes and the content of messages.

Accordingly, Tomaselli [232-263] uses the case studies of "Classified People", "Girls Apart" and "Maids and Madams" to disclose dominant relations of power, dissect the political economy of domestic service, the ambiguity and often nebulous nature of multiple voices, the structured silences, in structuring and determining the form/substance/ dimensions of crew-subject relations, the refiguring and realignment of social practices in the quest to identify, both conjuncturally and organically, in terms of ever-present time-space dialectic, universal tendencies within the network of myriad specificities, a methodology sui generis in resper.t of documenting, narrating and interpreting of the human condition. Accordingly Tomaselli provides, as a prerequisite preface to his detailed analysis of sense- making, richly-textured operational definitions, varied taxonomic circumscriptions, and multi-layered differentiations within subcategories constituting the methodological index of a critical semiotics, accenting 
discursive components or inflexions such as signs, signifiers, codes and texts [30-39, 48]. Tomaselli [29] centers the historical materialist basis of sense-making and considers it first and foremost as a transformative act: a conscious, deliberate act contesting dominant relations of power. Hence, with a view to understand the conjunctural issues facing transformative sense-making, he states that semiotics involves the study of how meaning occurs in language, pictures, performance and other forms of expression. The method incorporates not only how things come to mean, but how prevailing meanings are the outcomes of encounters between individuals, groups and classes and their respective cosmologies and conditions of existence. These social and cultural categories are crisscrossed by other lines of tension such as gender, psychology, religion, language, ethnic and nationalist forms of domination and/or resistance. Overlaid on all these is culturehow specific groups of people encounter, make sense of, and ascribe meaning to, the respective social, mental and physical worlds into which they are born, in which they live and where they usually die. These encounters and conflicts are manifested in semiotic struggle. All kinds of representations embody and conceal their conflictual histories. Individuals are thus themselves sites of contradictory tensions as they move through multiple trajectories and dominant and counter-meanings [29].

Accenting the dialectic of domination/resistance throughout his text, Tomaselli [29-49] manages to capture, quite effectively, the axiomatic presence of "change as the only constant" in the construction/transcendence of specific images, symbols, and codes undergirding particular textual/ contextual meanings, discursive formations and truth regimes [cf. Said 1994]. It is also this open-endedness, fluidity and perpetual flux in substance, form and meaning of text, context, sub-text of specific histories, memories and existential realities that constitute the possibility for an alternative reading or interpretation of human development [cf. Rist 1999]. Stripped of the metaphysics of "frozen meanings" and "teleological" destinies-the eventual outcome of a pre-arranged directory and trajectory of human travails in "a valley of tears"-the dialectic of constant interplay, negation/mutation ushers in the semiotics of change, that is, reconfiguring the prevailing relations of power so as to disclose, signify and affirm the immanent meanings, potentiality, insights and thus empowering choices for the historically marginalized and excluded [cf. Wolfe 1996]. It is in this sense that the Peircean concept of phaneron is pregnant with the tensions of an alternative reading/direction/trajectory of the human condition, especially in relation to the "Other" [55-88; 161-229]. Tomaselli emboldens the concept of "concealed text" [55] to accent the partial reading, interpretation and understanding of the nonmaterial realm which is beyond the phenomenal world. With the view to distinguish between a positivistic approach to human experience and a more "engaged approach" to the Other he defines and employs, dialectically, not metaphysically and ahistorically as some of his critics4 claim, Peirce's concept of phaneroscopy to anchor his ensuing analysis of "indirect knowledge" of reality, i.e. "encounters within which people make sense of their worlds" ISS]. Here Tomaselli \{56] explains that "encounter entails several possible experiences between an interpreter and an event or situation. The phaneron- all that is present to the mind in such an encounter-pre-exists the sign. Signs, then, are the vehicle through which experience becomes intelligible". Tomaselli \{56] states that "phaneroscopy is the only philosophical concept currently available to help explain discourses threaded with the spiritual and para-normal, dimensions of belief and 'reality' excluded by the concrete emphases of First 
World social science". In relation to the practical significance of this operational concept for understanding the human condition, especially in "developing/non-western" countries, Tomaselli f63] concludes: "The phaneron ...involves the interpreta- tions of both producers [conceived texts] and viewers \{perceived texts] into a total framework of meaning [social texts] which may have little to do with the 'reality' that photographers, film-makers, and ethnographers think they may have cap- tured or explained" \{original emphases]. These variegated structural processes of sense-making imply both the demythologization and radicalization of know- ledge, transcending, thereby the limits and limitations of metaphysical, linear, unfocal modelling \{Tomaselli 1996: 37]. The focus is thus on open-endedness, flexibility, multi-dimensionality in researching and interpreting the construction, dissemination, communication, reproduction and transformation of particular images vis-a-vis the human condition. Even so, as Boff [1987:42] points out, "[w]e can never grasp the totality of reality as such, but only by means of historical models that ought always to be confronted with reality and enriched, criticized, corrected and open to internal growth and built-in obsolescence". Thus specific meanings are always contextual and profoundly influenced by particular experiences within and across different cultures fcf. Said 1993].

In Tomaselli's view, the need to contextualize specific meanings arises from "the indeterminacy of language which exists between, and which responds to, the different ontologies and ways of knowing and making sense that typify literate versus oral cultures, amongst others" \{60]. Accordingly, "the literal meaning of texts \{words] cannot be absolutized, but merely understod as an exemplary apprehension within a specific \{sociohistoric] model" [Boff 1987:42].

In historical-materialist terms, Tomaselli's text illustrates that language relays ideas, views and perspectives among human beings; i.e. it functions, albeit in vari- ous forms of effectiveness, to transmit accumulated human thought an practices across time and space whether in written and/or in verbal form [Shukman 1988]. Indeed, as elucidated in Pierre Bourdieu's seminal text of 1991, Language and Symbolic Power, language functions as a descriptive/nominal, analytical/surgical, interpretive/hermeneutic and comprehensive/integrative means of sense-making and is, differentially, predicated upon a given and changing repertoire of linguistic devices (words designating various degrees of material/ critical content). Even so, as pointed out by Bourdieu [1991], it still has to be noted that the current denotative limitations of language foreclose the complete cognitive, heuristic encapsulation of a multi-dimensional social formation in structured, generative, transposable semantic terms. Hence the need to devise and employ conceptual frameworks which transcend the existing limitations of the socially structured, parametrical and interpellative strictures of prevailing linguistic codes and designs in an effort to capture, more precisely and effectively, the reality of a differentiated human experience in the totality of its historical setting. This means that sense-making within a specific discourse, i.e. the particularized use of words and phrases accenting specific inflexions, nuances and meanings, is, amongst others to: enlighten the reader [cf. Mills 1959]; acquaint the listener [cf. Foucault 1980]; instruct the subject [cf. Memmi 1965]; inform the dependent [cf. Marshall 1990]; advise the enquirer [cf. Gutierrez 1988a]; describe patterns [cf. Laclau 1987]; specify actions [cf. Giddens 1984]; expose incongruities [cf. Kuhn 1970]; detect tensions [cf. Harvey 1996]; pilot novices [cf. 
Gouldner 1985]; guide learners [cf. Lefebvre 1988]; impart knowledge [cf. Lyotard 1984]; apprise decision-makers [cf. Fedoseyev and Timofeyev 1981]; disclose sophistry [cf. Meszaros 1989]; indic- ate nuances [cf. Fay 1987]; suggest remedies [cf. Fanon 1963]; express viewpoints [cf. Eagleton 1983]; declare intentions [cf. Corrigan 1990]; announce plans [cf. Bourdieu 1988]; intimate congruence [cf. Aronowitz 1988]; note distinctions [cf. Amariglio 1988]; record events [cf. Barchiesi 2000]; explain mysteries [cf. Anderson 1983]; report findings [cf. Gutierrez 1988b]; disseminate informa- tion [cf. Reason and Rowan 1981]; signify trends [cf. Therborn 1980]; assert positions [cf. Sartre 1977]; represent perspectives [cf. West 1993]; shape thoughts [cf. Freire 1973]; influence decisions [cf. Fanon 1967]; encourage rigor [cf. Godamer 1987], accent similarities and integrate the individual into a society by means of effective communication, dialogue and understanding that is reciprocal yet reflective of the intellectual capacity of the person in question [cf. Pecheux 1988; Freire 1970, 1985; Freire and Shor 1987; Freire and Macedo 1987].

Still, though, it has to be stressed that not merely is the cognitive process (i.e. how we come to understand social reality) complicated by the parametrical limitations of linguistic codes (i.e. particular words cannot have infinite meanings), it is also made more difficult by the ever-changing nature of prevailing social pro- cesses (i.e. motion in matter affecting all social relations of production, circulation and reproduction) [Foucault 1973; Castells 1996, 1997, 1998]. Hence Soja [1989: 2], for example, observes:

What one sees is stubbornly simultaneous, but language dictates a sequential succession, a linear flow of sentential statements bound by that most spatial of earthly constraints, the impossibility of the two objects [or words] occupying the same precise place [as on a page]. All that we can do is to recollect and creatively juxtapose, experimenting with assertions of the spatial against the prevailing grain of time. In the end, interpretation can be no more than a beginning [of understanding].

It is precisely this highly differentiated role/ascribed capacity of language which Tomaselli explores in his text [cf. Colomb 1987; Chomsky 1988]. In interpreting specific films, he takes as his point of departure the energies, needs and desires operative at the popular level. Thus he privileges a grassroots-oriented, bottom-up approach, allowing for an enabling reading of films. As a resultant, his interpretation of films discloses and reinforces a number of interrelated historical materialist oriented perspectives, viz: films are fundamentally social as they draw on and reproduce social discourses; thus they are socially discursive acts. Films presuppose social codes of perception which allow them to be decoded by audiences. The external object or referent that film sociology posits is always a construct of the semiotic or rhetorical operations of film discourse. Social conventions allow referents to assume objective or "real" status. The literal referents in a film are actors and sets. The references to history and society that films generate or presuppose are themselves mediated by other social discourses. More importantly, perhaps, the social context within which films are produced and distributed and viewed is itself interwoven with discourses of class, race, sex, ethnicity, nationality, work, personal narratives and information systems. Accordingly, representational and perceptual conventions operate as a grounding framework of film production, distribution and viewing. Since films enunciate meaning through discursive operations, and because social 
reality itself is mediated by discourses, films are a subset of social processes and not a separate category thereunto. For example, the narratives and stories in films are also at work in everyday life, as the stories people tell themselves to make sense of their lives, as the narratives people live out when they perform certain actions of work and play, and as scenarios that script events which they follow in particular ways (e.g. socializing, protesting, resisting oppressive social policies and practices). Ontologically, this means, amongst other things, as social beings humans inhabit systems of signification: their lives are structured by codes of valorization such as aggressive/ nonaggressive; dominant/nondominant patterns of behavior, which, in tum, influence or determine the range of their social action.

Tomaselli's text also discloses that multi-dimensional interactive social pro- cesses are operative in films: for example, though in film the "model" of discourse is linguistic, the film and the viewing subject are nonetheless in communication, i.e. they intersect, through a mediated process of intersubjectification. More specifically, images, narratives and beliefs in relation to a particular social reality are screened/interrogated through a cinematic lens of portrayal, digestion and reflection. From this multi-layered interactive process derives a more differentiated and situational understanding of how specific films address varied audiences and generate different meaning effects in particular contexts. Film representations enlist audience identification or sympathy with different sides in social debates and social struggles. This interactive relationship between audience/participant/ subject and film is possible for two reasons. First, a person's sense of self or identity is constituted through identifications with social objects, images of which are internalized (such as the nation, the family, class, etc. [Young 1995)). Second, perceptions and ideological positions are shaped or influenced by shared value systems/frames of reference either to disrupt or cohere socially acquired norms/ values and patterns of identification-reasserting established value systems or contesting dominant relations of power inscribed and reinforced through hegemonic social practices, institutionally, collectively and personally [Tomaselli et al. 1986]. This also means that films can reposition, realign, and/or change dominant discourses and images-as a registry of permanent possibilities-by providing enabling, empowering and thus transforming knowledge vis-a-vis the human condition [cf. Ryan 1988].

The above transformative potential of film is possible, precisely because

[w]e use words [as] instruments, and models by which we understand others and ourselves and which are taken from the cultural world about us. Our concepts and formulas constitute the exterior and fragile vase that preserves a precious essence ...Though the precious essence be represented in an imperfect manner, it is always expressed within a language that is comprehensible to a particular epoch. [Boff 1987: 182)

Construed in such contextual terms, it is possible to apply semiotics to the vexed question of "development". Here the foundational premise is: if specific dis- courses-as disclosed and reinforced by Tomaselli's text-create specific visual representations/images about the human condition, then the question looms large: Development in whose image? This question is explored in the ensuing section. 


\section{The semiotics of development: in whose image?}

In the preceding section it has been stated that Tomaselli's text discloses the historicallydriven, materially grounded form, content and dimensions of images produced, disseminated and appropriated in ethnographic films. With a view to linking these interpretive, thematic constructs undergirding ethnographic films to the semiotics of development, it is necessary to introduce a number of operational premises.

First, if films comprise elements such as characters, actions, settings, then by hermeneutic extension it can be argued that the concept, content, and dimensions of development are equally infused by such structuring components. In this instance, the characters of development comprise development policy analysts/ advisers/think-tanks/ experts; the actions entail development projects, programs; and the settings involve those geographical areas in the world which have been designated by "leading/influential" international agencies, such as the World Bank, the International Monetary Fund (IMF) and various organs of the United Nations, as being in need of and/or warranting "development" support/assistance/donor aid [cf. Caufield 1998]. These discursive interventions and operational aspects of development also derive their meanings and values from existing social systems of signification [cf. McMichael 1996].

Second, the prevailing social discourses of encoded meanings (of each social element within development policy/practice) derive their significance from the structural relations of power, i.e. from a certain position in the social system or of being in differential relation to other elements in the system, for example as male/female, rich/poor, white/black, capitalist/worker, developed/developing country [cf. Markoff 1996]. As in the case of films, this means each of these elements assumes value differentially and relationally through its difference from other elements within the discursive or operational practices of development; hence the unequal relations of power in the production, circulation, consumption and reproduction spheres of development. More specifically, each element is encoded by possessing or not possessing certain traits vis-avis particular development discourses and practices, thus, in historical terms, the interpellation such as "developed/ developing/ underdeveloped/ poor /highly indebted countries/highly indebted poor countries". Concepts and theories of development incorporate these elements, recodify them to create specific images/meanings and values specific to a particular social formation [Harvey 1996; Castells 1996, 1997, 1998].

Third, as in the case of film, in development discourse, the social world becomes a system of contested/appropriated visualization/discursive [dis]articulation and valorization, in terms of historical constructs and binary terms such as coloni-alism/independence, democracy/dictatorship, rich ruling elite/the poor masses [Young 1995; Mamdani 1996].

Based on the preceding premises, it can be suggested that in human experience (an existential reality) there is a dialectical link between active reflection (a theoretical activity) on certain social conditions and the resultant practical action to change the undesirable social conditions such as homelessness, illiteracy, unemployment, and so forth (abstract concepts 
operationalized) [Burgess et al. 1997]. Hence "theory" and "practice" are not dichotomous activities in origin and form but exist in dialectical unity [Seidman 1994]. Thus the possibility of, and need for, an interpretive discourse on, and not merely a descriptive narration of, the ever-changing, multidimensional nature of society [Ellin 1996]. Such a dialectical understanding of society is, for example, in direct contrast to the dominant model-building scenarios of policy-makers which tend to emphasize, almost exclusively, the unproblematic "integration" of diverse, contradictory elements in society in the name of the rather elusive notions of stability, harmony, consensus and nationbuilding [Sassen 1994]. Alas, history has always been a trajectory of contradictions, tensions, conflicts, struggles and change and not one of equilibrium, the much-vaunted aims of model-building notwithstanding [cf. Hobsbawm 1997]. Hence, the contestation between empirical oriented, factfinding research- ers as opposed to dialectically-inclined, interpretation-bent researchers, with the latter focusing on explanation and interpretation and the former accenting descriptive and procedural enquiries that usually result in a maze of constructivist relativism-the Baal of developmentalism [Ragin 1994]. More importantly perhaps, in the construction of specific images about the human condition, theoretical activity or work in itself does have a practical utility or impact insofar as it influences and even orients how a person or group of per- sons respond to specific social issues [cf. Giddens 1979; Harvey 1973; Laclau 1987]. In short, sound theory informs, enlightens and broadens human under- standing even if the material conditions for its application within a specific social formation would, in the immediatist sense of the word, as yet not be opportune [cf. Freire 1970]. Ideally, therefore, equipped with a sound theoretical understanding of society, people organize and mobilize to facilitate the explosion of the underlying tensions and contradictions in society, so as purposefully to create the material conditions conducive to the implementation of the materially-oriented principles derived from a particular theory [cf. Markoff 1996].

Dialectically-driven theoretical perspectives, as opposed to descriptive discourses, are thus informed by the realization that for every obvious "fact" we experi- ence there is a hidden, more profound basis upon which such apparent fact rests [cf. Meszaros 1989]. To understand the "fact" in its complexity and its unfolding dynamic nature we need to understand its very foundation-often multi-layered and complex-from which it originates. Such an understanding is driven by the very substance of human history-the meaning of life, the purpose of one's presence in the world, constituting, paradoxically, the very basis of all creative and dynamic thought and action [cf. Svitak 1970]. Methodologically and hermeneutic- ally, this means that a theory represents a particular way of conceptualizing and understanding human experiences. It orders, arranges and outlines a specific area of human enquiry, explains its inner structure and dynamics and indicates the range of possible responses to it. It orients the thoughts of people, fosters their sensibilities and attitudes and frames their expectations, and in general gives them an intellectual and moral compass [cf. Parekh 1992]. 
In relation to the concept of development, Apter [1987: 15], for example, observes that "[w]e are talking about the power to appreciate the larger picture, to understand what lies behind events, and to think our way beyond present circumstances". Still, though, it has to be recognized that who we are and where we are going are fundamentally shaped by our engagement in the real world and that it is only through our accumulated experiences that the future could be designed, that is, the transcendent "beyond" cannot be shaped outside human experiences of time, place, context and material reality [cf. Gutierrez 1988b]. Apter [1987:42-44] states further:

Theory then is the product of reflection and interpretation arriving out of the relation between event and text, experience and abstract knowledge. In this respect, events constitute a social text, read, interpreted, and made coherent in terms of broader principles, such a social text stands on its own. It represents interpretation as a form of evidence on its own ...Itis when ordinary things are suddenly charged with meaning and stand for larger devices-retrieval and projection, narrative and myth, logic and theory-that an enriching process occurs, a reinforcing particularity so that icons, markers, traces, can be mobilized as mytho-logics of terror, insurrection, protest with symbolic destiny.

Theoretically, it can thus be argued that the image of (what constitutes) development is a site of struggle, a terrain of contestation, where the meaning, substance, form and overall dimensions of human progress are not frozen in time or space, but subject to the relations of power within a specific social formation [cf. Seidman 1994). More specifically, the dominant relations of power, determining the content, form and direction of development, conjuncturally, derive from the balance of class forces that (seem to) operate in such a way that they elicit structurally, even though not democratically, the consent of the dominated and marginalized in society [cf. Rist 1999]. Hence the bourgeoisie in capitalist society rule in large part because they have managed to arrange or elicit the structural allegiance of the "people" in such a way as to make it appear that they have the "natural right" to do so. This consent occurs because of what Gramsci [1971: 12-13, 55-6o, 416-418] calls the "hegemony" of the bourgeoisie. "Hegemony" involves the ideological domination of one class by another to the extent that the conceptions, images, symbols, concepts, theories, discourses of the dominant class--on what exists, what is appropriate, what possibilities are open to it, and what it should "rightfully" expect-buttress, and thus reinforce, their position vis-a-vis the subordinate class. 5 Accordingly the ruling class assume a cultural ascendancy the subordinate class. 5 Accordingly the ruling class assume a cultural ascendancy on the basis of which they secure loyalty of those whom they dominate. This is precisely what Heinrich, a subscriber to the University of the Witwatersrand electronic Debate List [debate@sunsite.wits.ac.za; 15 March 2000] accents, when he, with reference to the South African government's Growth, Employment and Redistribution [GEAR] policy, writes: 
I don't think Gear has failed at all! ...It has disciplined labour; liquidated the humanities; marketised social services; intellectualised poverty; 'freed' markets; de-bugged civil society; publicized policy; repressed hostility; communicated ideology; adjudicated social conflict and generally inaugurated a political culture that can generate little opposition, let alone, 'alternatives'. [Its authors] may be economists by training, but they didn't sit down to write a text-book that has demonstrable errors. The [intended] effects of their work was [sic] intensely political. To deal with either them or Gear on another terrain-is to make a category [sic]mistake.

This means, at least conjuncturally, GEAR provides the dominant concept, theory, discourse and image of what constitutes development in the "New South Africa". The overriding control by GEAR of all sectoral issues in relation to development thus operates as both the conceptual and theoretical limitation on the directory and trajectory of development in South Africa, and constitutes simultaneously a paradigmatic totalization of specific possibilities, interpretations, and forms of sense-making vis-avis the human condition in post-apartheid South Africa. It is this theoretical/ conceptual circumscription, and the resultant totalization of a specific form/image and type of sense-making (in the realm of development), that constitutes cultural hegemony.

\section{Cultural hegemony: sense-making in relation to the development Problematique}

In this section it is suggested that, conceptually and theoretically, cultural hegemony informs and undergirds the semiotic features, operational and hermeneutic dimensions of sense-making. For example, through a process of signification and interpellation the dominant relations of power determine the cultural capital of a society; reducing the marginalized, in the parlance of the Brazilian pedagogue, Paulo Freire [1970: 27-74], to a state of "cultural silence". 6 Freire asserts that the cultural domination of the marginalized takes place through the employment of various social practices. He states that [a]ll domination involves invasion-at times physical and overt, at times camouflaged, with the invader assuming the role of a helping friend. In the last analysis, invasion is a form of economic and cultural domination ...Cultural conquest leads to the cultural inauthenticity of those who are invaded; they begin to respond to values, the standards, and the goals of the invaders. In their passion to dominate, to mold others to their patterns and their way of life, the invaders desire to know how those who have been invaded apprehend reality-but only so they can dominate the latter more effectively. In cultural invasion it is essential that those who are invaded come to see their reality with the outlook of the invaders rather than their own; for the more they mimic the invaders, the more stable the position of the latter becomes. [Freire 1970: 150-151]

In like manner, Frantz Fanon [1967: 233), the Martinique-born, Algerian med- 
ical activist, captures the dialectical nature of culture vis-a-vis sense-making, perhaps most effectively when he avers that [a] national culture is not a folklore, nor an abstract populism that believes it can discover the people's true nature. It is not made up of the inert dregs of gratuitous actions, that is to say actions that are less and less attached to the ever-present reality of the people. A national culture is the whole body of efforts made by a people in the sphere of thought to describe, justify, and praise the action through which that people has created itself and keeps itself in existence.

Thus, both Freire and Fanon emphasize the relations of power undergirding specific cultural practices. Dominant cultural practices serve to elicit and sustain the consent of the dominated and governed in society. Conceptually and praxeologically, therefore, consent derives from a structural context which is manipulative and ultimately rests on the capacity to coerce through violence.

This implies that the consent the dominant class enjoys is not free consent because it results from the manipulation which is part of the system as a whole. Access, in capitalist society, to the general public is limited to those who have the resources to afford the costs involved, and those who have these resources are generally those who control the means of production or who are allies of those who control these means [cf. Caufield 1998]. In the construction and dissemination of specific operational concepts and images of development, for example, the production of books, newspapers, television or radio programs, and the like, is in theory open to all, but in fact is open to only the ruling class and their allies. In the field of education, for example, educational institutions depend on the financial and social support of the bourgeoisie such that if schools do not do what the bourgeoisie approve, their support will not be forthcoming, and the institutions will gradually wither [cf. Barchiesi 2000]. The same is true of the state. In principle, electoral candidacy is open to anyone who wishes to stand, but in reality only those who have access to money can run for office. In all these cases, access is cardinally important in orienting, even dictating, public culture, and the form, content and dimensions of specific concepts, theories, and thus images of the human condition.

Indeed, it is those with access who set the public agenda, who provide the vocabulary and ideas in terms of which the agenda is discussed, and who report on the outcome of the ensuing discussion. Public culture is thus the result of a filtering process in which only positions acceptable to those who rule are available to the dominated. More importantly, behind this manipulation is the capacity to coerce. Those in charge of the reproductionist institutions in society have available to them the means of punishment by which to control those who do not willingly follow their lead. This is particularly true of the state with its armies and police force, but it is also true of teachers, employers, parents, priests and so forth. In all power relations consensus is backed up by force, reinforcing the consensus by the threat thereof. This force always becomes more evident as consensus erodes and the position of the more powerful becomes precarious in the counter-hegemonic struggle to transform the dominant relations of power in society at large and in 
specific sectors in particular [cf. Gramsci 1971:108-110,229-239]. More importantly, perhaps, it is transformative sense-making that characterizes and underlies the differing concepts, theories and images that undergird and inform specific counterhegemonic policies, projects and programs in the struggle to either entrench or change the status quo.

\section{Towards transformative sense-making}

Transformative sense-making suggests that the dominant sites of interest do not merely function to produce and reproduce specific relations of power: they them- selves are constantly being reconstituted and realigned by the ruling bloc to maintain and entrench the status quo [cf. Hall 1988]. Also, even though these sites function differentially, yet concurrently, to sustain the dominant relations of power they nonetheless can be and indeed often are contested by the interest groups/ forces in the counter-hegemonic bloc through a range of organizational tactics, strategies and political action [cf. Williams 1989].

This counter-hegemonic, change-inducing, transformative sense-making strategy resonates with the works of the Brazilian scholar, Paulo Freire [1970: 119-186; 1973: 3-164; 1985: 167-199; see also Freire and Shor 1987: 121-187, Freire and Macedo 1987: 141-169] on "conscientization", which he defines as the process of becoming aware of the socio-economic-political tenets and practices undergirding a specific social formation.

In locating conscientization in historical materialist terms, Freire indicates, as stressed earlier in this essay, that the ruling class maintains its hegemony by subjecting the marginalized to a state of "cultural silence", leaving the status quo largely "undisturbed" and thus intact-irrespective of the severity of the existing, oppressive/repressive and exploitative relations of power. However, through sustained struggle the marginalized are able to radicalize their sensemaking of the status quo, thereby establishing the transformative umbilical cord, the dialectical link with the process of "conscientization" . Accordingly, transformative sense-making of the status quo becomes a possibility, engendering thereby, in varied degrees, forms of clarity, elucidation and enlightenment, thus making it possible for the marginalized, the excluded, the Other to interact with the world as sense-making, meaning-conferring, changeinducing subjects. It is in this regard, of transformative action, that Freire stresses the import of self-expression or self-realization, i.e. the state of becoming aware that one can name, initiate, direct, change, alter, reform and transform things in the interests of a socialized or collective humanity. It is ultimately in the collectivity of human experience that the individual discovers the meaning and purpose of his/her life. Indeed, this is also the view expressed more than a century ago by Marx and Engels [1966: 74], when they stated that "[o]nly in community with others has each individual the means of cultivating his gifts in all directions; only in the community, therefore, is personal freedom possible". 
This means, amongst other things, that outside the collectivity the individual is merely a floating entity in the universe of socialized humanity. Humankind is meant for togetherness, understanding, cooperation, and not separation, rivalry and alienation. This suggests, amongst other interpretations, that human development is not to be confined merely to the economic realm, but should extend to the ethical, moral and "spiritual" domain as well. Indeed, even the World Bank [20oo] recognizes that a lack of human development (poverty) entails psychological suffering as well, i.e. "powerlessness, voicelessness, despondency, shame and humiliation".

Thus, as suggested earlier in this essay, whilst most scholars seem to neglect the overall import of the more "mythical realm" of human life, it cannot be disputed though that the mythical element of a particular social reality assumes a very important place in the daily practices of humankind [Boff 1986]. Marginalized people quite often "withdraw" or are forced to withdraw into the mythical realm to contemplate about a social formation beyond the oppressive and exploitative forces in their daily lives. It is precisely at this level where the stark reality of oppression and exploitation interfaces with the transcendental realm of hope, inspiration, consolation, even escapism, that the transformational intervention by the counter-hegemonic bloc should occur. It is simply not enough to write off these forms of contemplation and escapism as "false consciousness". On the contrary, it is ultimately important to realize the status quo reinforcing nature of these forms of "social distancing".

On the other hand, these mythical/metaphysical discourses on reality-for example, a belief in an omnipotent God enabling socially conscious people-can be used to mobilize and empower subordinate communities in their struggle for justice [cf. West 1982 and Boff 1988]. Thus it must be realized that the people's modes of interaction with the world, in all its multiple dimensions, can be used either to entrench a specific social reality or to transform an existing order. It is for this reason, amongst others, that Tomaselli [1996: 155] also indicates in his text that the greatest drawback among Western scientists and social activists is their "constructed" incapacity, through their exposure to specific forms of education and knowledge, to "enter the world" of the marginalized, oppressed, exploited and culturally silent. Also in this respect, the illustrious Italian scholar, Antonio Gramsci [1971], yet again provides some theoretical leverage to advance transformative sense-making in challenging and changing the dominant relations of power in society.

In this regard, Gramsci [1971] recognizes the overall import of myths, what he calls popular feelings/ in so far as they are embedded in the prevailing social practices of people. For him, myths contain a materiality of their own precisely because they influence, if not determine, the nature and orientation of human thoughts, dispositions and practices. Hence myths do not operate as "illusions-inabstraction", but as "illusions-in-action", the driving force behind specific forms of social relations of subservience/authority, production/reproduction. What 
this conceptualization of myths implies, amongst other things, is that, in terms of a critical consciousness, conscientization, enlightenment and transformative sense-making, they need to be deconstructed and reconstructed in the interests of the subordinate, the excluded, the other-a potential counter-hegemonic bloc to effect fundamental social change. In this regard, Gramsci views the role of organic intellectuals in society as being of cardinal importance. In his view, intellectuals are part of a specific class and movement who serve to give it an awareness of its own function not only in social fields but also in political fields. Thus asserts Gramsci [1971:418]:

[t]he elementary passions of the people, understanding them and therefore explaining and justifying them in the particular historical situation and connecting them dialectically to the laws of history and to a superior conception of the world, scientifically and coherently elaborated-i.e. knowledge. One cannot make politics history without this passion, with- out this sentimental connection between intellectuals and people-nation are, or are reduced to, relationships of a purely bureaucratic and formal order.

Thus, in both the Gramscian implied notion of "enlightenment" and the Freirian concept of "conscientization" the marginalized in society are able to make sense of obscured, hidden practices within society, thus constructing the hermeneutics of transformative action. It is in this regard, where Tomaselli's notion of "relexification" [Tomaselli 1999: 137] engenders a contestatory reading, understanding of prevailing material conditions, thus containing the potential to offer strategies for coping with, and overcoming, oppression [Tomaselli 1999: 40]. Hence the import of effective communication, which, for Tomaselli [1999: 41] "is really more about power relations and control over who defines meaning than it is about the 'sharing' or 'exchange' of information" [1999: 152-:153]. Accordingly, with the view to enhance the transformative sense-making amongst the excluded, the marginalized, the subordinate, the Other, it is necessary to recognize transdisciplinary sense-making as a sine qua non to transform the dominant relations of power within and across all sectors of society.

\section{Transdisciplinary sense-making to transform the human condition}

Making sense in Tomaselli's oeuvre is a profoundly human enterprise of either reinforcing or transforming the dominant relations of power. In his varied semiotic excursions one finds a whole range of defining and informative disciplinary trajectories constituting a dialectical unity, where both specific and general, experiences on the canvas of image-making and un-making vis-a-vis the human condition are concretized, disclosed, narrated and presented as potentially empowering constructs in the quest to establish a more equitable or global order. Hence the suggestion to promote the transdisciplinary reading of texts, contexts and sub-texts, by focusing, amongst others on:

The Philosophy and Epistemology of Development: Its links with political studies, economics, education, planning, history and philosophy [cf. Dyer 1997; Rist 1999]. 
Economic Development: Competing theoretical perspectives vis-a-vis demographic patterns, social stratification, social groups, social structures, specific societies, civilizations, economic institutions, political institutions, etc. [cf. Caufield 1998].

Political Development: The origin, development and resolution of conflict in society with special reference to social movements or labour movements and their role vis-a-vis fundamental social change, development, and progress; competing perspectives on the state; the state and bureaucracy [cf. Markoff 1996].

Cultural Development: The regulatory modes of human behavior, i.e. the role of force in social life, custom and public opinion, religion and morality, law, education, etc. [cf. Said 1993; Griswold 1994; Young 1995].

Urban Development: Urbanism and everyday life with special reference to the import of social policy and social planning [cf. Burgess et al. 1997].

Social Development: The family and gender relations [cf. Delphy 1988; Franco 1988; Lesage 1988;MacKinnon 1988; Seidman 1994].

Geography of Development: Capitalism and the world system: modernization theory, the nation-state, nationalism, and so forth [cf. McMichael 1996].

Transformative sense-making furthermore requires the radicalization/ deepening and appropriation of the preceding sectoral/ categorical referents by harnessing a range of semiotic skills.

\section{Semiotic skills}

The cultivation of transdisciplinary semiotic skills presupposes access to quality education. Here it is readily granted that, in historical materialist terms, "education" is not an atomistic, nebulous, metaphysical/teleological-driven entity but is profoundly shaped by the specificities and contingencies of particular historical tensions, contradictions, conflicts, movements and struggles [cf. Barchiesi 2000]. Thus, whilst mindful of the contestatory nature of the form, substance and dimensions of education, it is nevertheless suggested that, with the view to advance the semiotics of transdisciplinary engagement, reflection-as implied by the multi- dimensionality of being-in-the-world, as both cognitive and social being-it is necessary to acquire and inculcate a range of critical sensemaking skills such as:

- epistemological skills-i.e. the ability to probe the origin, nature and development of specific sets of knowledge;

- heuristic skills-i.e. the ability to interpret, in a rigorous manner, the empirical veracity and conceptual dimensions of certain truth claims; 
- ontological skills-i.e. the ability to demonstrate the empirical existence of particular phenomena as historically driven entities within an ensemble of ever- changing relations of power;

- axiological skills-i.e. the ability to indicate, in a coherent, logical manner, the overall nature, dimensions and substance of particular societal weaknesses pre- figuring society's potential disintegration;

- deontological skills-the ability to delineate the possibilities of facilitating the emergence, development and sustenance of pedagogically sound and sociologically tenable institutional practices, mores and codes of conduct, thereby instilling and advancing the common good in society at large;

- eschatological skills-the ability to extrapolate existential experiences, human behavior and practices on the basis of historically driven tendencies, trends and overall patterns with a view to ensure a sustainable future for generations yet to be.

Critical sense-making skills without application are useless. Hence the import of "measuring" the effectiveness of sense-making skills in relation to specific daily (routine) engagements as suggested in the ensuing section.

\section{Effective, transformative sense-making}

In an inequitable, changing social order, both locally and globally, the effective- ness of such skills would be borne out by work if it:

- has impact and influence and is thus inspiring;

- is achievement-oriented and is thus proactive;

- is based on information seeking and thus instills the ethos of information search;

- reflects rigorous, thorough, coherent planning and organization, thus enhancing dynamic concept formation associated with visionary leadership;

- is informed by problem solving and analytical thinking, thus facilitating strategy formation;

- enhances the developing of organizational talent and is thus crucial to coaching of meritorious achievers;

- recognizes dialogue and sensitivity in the formulation . and resolution of specific problems, thereby instilling a sense of and appreciation for interpersonal learning (sensitivity);

- is predicated on the principle of change being the only constant, thus encouraging cross-boundary learning and understanding;

- demonstrates an awareness of the information explosion and the need to be diligent in the execution of specific tasks.

The preceding pedagogical imperatives necessitate that we also make sense of the varied interpretations to which Tomaselli's text has thus far been subjected. 


\section{Conclusion: making sense of Tomaselli}

This essay has argued, through a review of the sense-making techniques in Tomaselli's text, that the image, concept, theories, substance, form, and dimensions of development are predicated upon the dominant relations of power in society. Itis therefore suggested that, with a view to change the human condition commensur ate with the basic needs of ordinary people, it is crucial to construct, cultivate and promote transformative sensemaking. This essay accordingly highlighted, through a selective reading/review/analysis of the work of the noted liberation theologian, Leonardo Boff, the acclaimed liberation pedagogue, Paulo Freire, and the eminent organic intellectual, Antonio Gramsci, that transdisciplinary sense-making is a sine qua non to reconstitute and transform the concept, theories, image, substance and overall dimensions of development. Making sense of Tomaselli's Appropriating Images: The Semiotics of Visual Representation, it has been argued, is a vital step in that direction. Ironically, whilst Tomaselli's text is a ground-breaking interrogation of extant methodological practices in the realm of visual anthropology, comprising a rigor- ous critique of "representational techniques" in the film/video/ethnographic industry, his own work, based on an original application of Peircean semiotics, has led two recent reviewers to pigeon-hole him as either methodologist [Shepperson 1998] and/or postmodernist [Milbrodt 1999]. Both these assessments are misplaced and based on an essentialist/reductionist reading of Tomaselli. On the contrary, in Appropriating Images Tomaselli displays a keen awareness of history, space and place, i.e. the Peircean methodology vis-a-vis sensemaking is context- driven. Human experience informs his methodology, orients his inquiries, and shapes his resultant interpretive/sense-making perspectives where the semiotics of othering is centered to disclose, existentially, unequal relations of power in the production, communication, dissemination and appropriation of particular images. Hisnumerous case studies, together with anecdotal evidence, derived from both primary and secondary sources, illustrate that his work is not ahistorical, as Shepperson implies [Shepperson's reference to the 19th century nature of Peirce's work, 1998: 270], nor is it largely methodological, as Shepperson states [Shepper- son 1998: 267]. On the contrary, Tomaselli's work is that of an engaged pragmatist a la Peirce who is profoundly concerned about human beings, especially the marginalized, excluded and voiceless in the here-and-now. Thus Shepperson's observation that "the book falls far short of doing justice to its own origins ....and that the reader doesn't get the real depth and breadth of implications of pragmatism as a ground for radical socio-political tradition" is both frivolous and cavalier. Inshort, Shepperson provides no supporting evidence for such sweeping claims. On the contrary, he appears to be contradicting himself when he states Tomaselli does not deny that peoples like the Kayapo and Yanomami of South America or the !Kung of Southern Africa have agendas which are based in other concerns than those which drive the multi-national corporations which tend to have the final say over what happens to images of such people [Shepperson 1998: 269).

Shepperson's suggestion, however, that there should be a sequel to Tomaselli's text "that will enable concerned professionals and intellectuals in other fields to benefit in the same way from the present book" [Shepperson 1998: 270] deserves attention. In like manner, Milbrodt's [1999: 109] claim that Tomaselli's work is "A Post- Modern Voice for the New Anthropology Student" is too categorical and detracts substantially from the 
epistemological reflexivity and historical materialist embeddedness of his text. Her claim that "Tomaselli has moved away from an Enlightenment perspective style of thinking" [Milbrodt 1999: 109] is at best a symptomatic reading or interpretation of his work and at worst a serious hermeneutic slippage and thus a gross distortion of his engaged and engaging text. On the contrary, as this essay has argued and demonstrated, Tomaselli's work is not a departure from an Enlightenment approach but a deepening, indeed, demythologization and thus radicalization of it by incorporating the other, the voiceless, the marginalized as sense-making, meaning-shaping actors in History.

Accordingly, Tomaselli's text should be read by all people who seek to acquire a critical/transformative understanding of sense-making and effective communication in the "new World Order" in general and in the New South Africa in particular. Eschatologically, the life-chances of generations-yet-to-be depend on such a demythologization and radicalization of human knowledge, understanding and sense-making in authenticating both the form and substance of human development in the 21st century and beyond. 


\section{Notes}

1. This text is, to a large extent, an extension of an earlier publication by Tomaselli, Williams, Steenveldt and Ruth Tomaselli [1986], Myth, Race and Power: South Africans Imaged on Film and TV.

2.Another question not posed by the author would be: how do the sense-makers make sense of themselves? A consideration of this question is beyond the scope of this paper and is mentioned here merely to serve as a potential catalyst for further research.

3. This section cites several passages from Boff's work in an attempt to illustrate the immanent and transcendental spatial/temporal reality of humankind-the central methodological focus of Tomaselli's work. In this regard, the excerpts from Boff's work complement Tomaselli's textual elucidation, reinforcing, thereby, his perspectives on sense-making, both theoretically and hermeneutically.

4.In this regard see for example Shepperson [1998] and Milbrodt [1999]. These two reviews are criticized in the concluding section of this essay [417].

5. In this regard the British cultural Marxist, Stuart Hall [1988:53-541, observes: "Hegemony is constructed, through a complex series or process of struggle. It is not given, either in the existing structure of society or in the given class structure of a mode of production. It cannot be constructed once and for all, since the balance of social forces on which it rests is subject to continuing evolution and development, depending on how a variety of struggles are conducted. Hegemony, once achieved, must be constantly and ceaselessly renewed, reenacted" (original emphasis). Hegemony, in capitalist society, assumes a number of different forms depending on the institutions involved: the state exercises political hegemony in that it defines the range of acceptable political options for the proletariat-the formation of labor unions and their range of permissible activities; the economic institutions-the corporations, the role of labor unions on the work fronthave economic hegemony by defining the aspirations and duties of the working class; and the other institutions of the capitalist system such as the nuclear family; and the state school system exercises hegemony over the proletariat by producing and reproducing the relations of production and reproduction vital to the status quo.

6. The concept of "conscientization" will be expounded later in this essay to illustrate its dialectical link to transformative sense-making.

7. Gramsci [1971: 418-432] discusses the significance of popular feelings in terms of a range of transcendental subjectivities such as religion, opinions, sensual indulgences, passions, beliefs. 


\section{References}

Amariglio, Jack L., Stephen A. Resnick and Richard D. Wolff 1988 Class, Power, and Culture. In Marxism and the Interpretation of Culture. Edited and with an introduction by Cary Nelson and Lawrence Grossberg. Pp. 487501. Urbana and Chicago: University of Illinois Press.

Anderson, Benedict

1983 Imagined Communities: Reflections on the Origin and Spread of Nationalism. London: Verso.

Apter, David

1987 Rethinking Development: Modernization Dependency and Postmodern Politics. London: Sage Publications.

Aronowitz, Stanley 1988 The Production of Scientific Knowledge: Science, Ideology, and Marxism. In Marxism and the Interpretation of Culture. Edited and with an introduction by Cary Nelson and Lawrence Grossberg. Pp. 519-541. Urbana and Chicago: University of Illinois Press.

Barchiesi, Franco

2000 South Africa: The Lean and Mean University: Tertiary Education Restructuring, and the Rise of Managerialism. InSouthern Africa Report (forthcoming).

Boff, Leonardo

1987 Jesus Christ the Liberator: A Critical Christplogy for our Time. Trans. by Patrick Hughes. New York: Orbis Books.

1988 Liberating Grace. Trans. by John Drury. New York: Orbis Books.

Bourdieu, Pierre

1988 Homo Academicus. Trans. by Peter Collins. Oxford: Polity Press.

1991 Language and Symbolic Power. Edited and introduced by J.B. Thompson.

Trans. By G. Raymond and M. Adamson. Oxford: Polity Press. Burgess, Rod, Marisa Carmona and Theo Kolstee

1997 The Challenge of Sustainable Cities: Neo-liberalism and Urban Strategies in Developing Countries. London: Zed Books.

Cape Times: 15 March 2000. Capra, Fritjof

1997 The Webof Life: A New Synthesis of Mind and Matter. London: Flamingo_ Publishers.

Castells, Manuel

1996 The Rise of the Network Society: Volume I: The Information Age-Economy, Society and Culture. London: Blackwell.

1997 The Power of Identity: The Information Age: Economy, Society and Culture, Volume II. Oxford: Blackwell.

1998 End of Millennium: The Information Age: Economy, Society and Culture, Volume III. Oxford: Blackwell.

Caufield, Catherine

1998 Masters of Illusion: The World Bank and the Poverty of Nations. London: Pan Books.

Chomsky, Noam 
1988 Language and Politics. New York: Black Rose Books.

Colomb, Gregory

1987 The semiotic study of literary works. In Tracing Literary Theory. J. Natoli (ed). Pp. 306-349. Urbana: University of Illinois Press.

Corrigan, Philip

1990 Social Form/Human Capacities: Essays in Authority and Difference. London: Routledge.

Delphy, Christine

1988 Patriarchy, Domestic Mode of Production, Gender, and Class. In Marxism and the Interpretation of Culture. Edited and with an introduction by Cary Nelson and Law- rence Grossberg. Pp. 259-269. Urbana and Chicago: University of Illinois Press.

Dyer, Richard

1997 White. London: Routledge.

Eagleton, Terry

1983 Literacy Theory: An Introduction. Oxford: Basil Blackwell.

1988 The Critic as Clown. In Marxism and the Interpretation of Culture. Edited and with an introduction by Cary Nelson and Lawrence Grossberg. Pp. 619-631. Urbana and Chicago: University of lliinois Press.

Eco, Umberto

1979 A Theory of Semiotics. Bloomington: Indiana University Press.

Ellin, Nan

1996 Postmodern Urbanism. Oxford: Basil Blackwell.

Fanon, Frantz

1963 The Wretched of the Earth. New York: Vintage Books. 1967 Toward the African Revolution. New York: Vintage Books.

Fay, Brian

1987 Critical Social Science: Liberation and Its Limits. Ithaca, New York: Cornell Univer- sity Press.

Fedoseyev, P., and T. Timofeyev (eds.)

1981 Social Problems of Man's Environment: Where We Live and Work. Moscow: Progress Publishers.

Foucault, Michel

1973 The Order of Things: An Archeology of the Human Sciences. New York: Vintage Books. $1980 \quad$ Knowledge/Truth. Colin Gordon (ed.). New York: Pantheon Books.

Franco, Jean

1988 Beyond Ethnocentrism: Gender, Power, and the Third-World Intelligentsia. In Marxism and the Interpretation of Culture. Edited and with an introduction by Cary Nelson and Lawrence Grossberg. Pp. 503-515. Urbana and Chicago: University of Illinois Press.

Freire, Paulo

1970 The Pedagogy of the Oppressed. New York: Continuum.

1973 Education for Critical Consciousness. New York: Continuum.

1985 The Politics of Education: Culture, Power and Liberation. Boston, 
Massachusetts: Bergin and Garvey.

1987 Education for Critical Consciousness. New York: Continuum.

Freire, Paulo, and D. Macedo

1987 LITERACY: Reading the Word and Reading the World. Boston, Massachusetts: Ber- gin and Garvey.

Freire, Paulo, and Ishra Shor

1987 A Pedagogy of Liberation. Boston, Massachusetts: Bergin and Garvey.

Giddens, Anthony

1979 Central Problems in Social Theory: Action Structure and Contradiction in Social Ana- lysis. Berkeley: University of California Press.

1984 The Constitution of Society: Outline of the Theory of Structuration. Cambridge: Polity Press.

Godamer, Hans-Georg

1987 The Problem of Historical Consciousness. In Interpretive Social Science: A Second Look. Pp. 82-140. Paul Rabinow and William M. Sullivan (eds.). Berkeley: University of California Press.

Gouldner, Alvin W.

1985 Against Fragmentation: The Origins of Marxism and the Sociology of Intellectuals. Oxford: Oxford University Press.

Gramsci, Antonio

1971 Selections from the Prison Notebooks. New York: International Publishers.

Griswold, Wendy

1994 Cultures and Societies in a Changing World.London: Pine Forge Press. .

Gutierrez, Gustavo

1988a A Theology of Liberation. New York: Orbis Books.

1988b The Power of the Poor in History. New York: Orbis Books.

Hall, Stuart

1988 The Toad in the Garden. Thatcherism among the Theorists. In Marxism and the Interpretation of Culture. Edited and with an introduction by Cary Nelson and Lawrence Grossberg. Pp. 35-73.Urbana and Chicago: University of Illinois Press.

Harvey, David

1973 Social Justice and the City. London: Edward Arnold Publishers. 1989 The Condition of Postmodernity. London: Basil Blackwell.

1996 Justice, Nature and the Geography of Difference. Oxford: Basil Blackwell.

Hobsbawm, Eric

1997 On History. London: Abachus.

International Publishers

1984 Dictionary of Philosophy. New York: International Publishers.

Kuhn, Thomas

1970 The Structure of Scientific Revolutions. Second Edition, enlarged. Chicago: Univer- sity of Chicago Press.

Laclau, Ernesto 1987 Politics and Ideology in Marxist Theory. New York: Verso.

Lefebvre, Henri

1988 Toward a Leftist Cultural Politics: Remarks Occasioned by the Centenary of Marx's Death. David Reifman, trans. In $M$ arxism and the Interpretation of 
Culture. Edited and with an introduction by Cary Nelson and Lawrence Grossberg. Pp. 75-88. Urbana and Chicago: University of Illinois Press.

Lesage, Julia

1988 Women's Rage. In Marxism and the Interpretation of Culture. Edited and with an introduction by Cary Nelson and Lawrence Grossberg. Pp. 419-428. Urbana and Chicago: University of Illinois Press.

Lyotard, Jean-Francois

1984 The Postmodern Condition: A Report on Knowledge. Trans. by Geoff Bennington and Brain Massumi. Manchester: Manchester University Press.

MacKinnon, Catharine A.

1988 Desire and Power: A Feminist Perspective. In Marxism and the Interpretation of Culture. Edited and with an introduction by Cary Nelson and Lawrence Gross- berg. Pp. 105-121. Urbana and Chicago: University of Illinois Press.

Mamdani,Mahmood

1996 Citizen and Subject: Contemporary Africa and the Legacy of Late Colonialism. Cape Town: David Philip.

Markoff, John 1996 Waves of Democracy: Social Movements and Political Change. London: Pine Forge Press.

Marshall, Gordon 1990 In Praise of Sociology. London: Unwin Hyman.

Marx, Karl, and Friedrich Engels 1966 The German Ideology. New York: International Publishers.

McMichael, Philip 1996 Development and Social Change: A Global Perspective. London: Pine Forge Press.

Memmi, Albert

1965 The Colonizer and the Colonized. Boston, Massachussetts: Orion Press.

Meszaros, Ivan

1989 The Power of Ideology. London: Harvester Wheatsheaf.

Milbrodt, Natalie

1999 [Book Review]: A post-modern voice for the new Anthropology Student. Critical Arts, 13(2): 109-111.

Mills, Charles Wright 1959 The Sociological Imagination. Harmondsworth: Penguin Books.

Parekh, Bhiku

1992 Marxism and the Problem of Violence. Development and Change, 23(3): 103-120.

Pecheux, Michel

1988 Discourse: Structure or Event? In Marxism and the Interpretation of Culture. Edited and with an introduction by Cary Nelson and Lawrence Grossberg. Pp. 633-650. Urbana and Chicago: University of Illinois Press.

Peirce, Charles Sander 1878 How to Make our Ideas Clear. [As cited in: International Publishers 1984: 312.] Ragin, Charles 1994 Constructing Social Research. London: Pine Forge Press. 
Reason, Peter, and John Rowan (eds.)

1981 Human Inquiry, A Sourcebook of New Paradigm Research. London: John Wiley.

Rist, Gilbert

1999 The History of Development: from Western Origins to Global Faith. London: Zed Books.

Ryan, Michael

1988 The Politics of Film: Discourse, Psychoanalysis, Ideology. In Marxism and the Interpretation of Culture. Edited and with an introduction by Cary Nelson and Law- rence Grossberg. Pp. 477-486. Urbana and Chicago: University of Illinois Press.

Said, Edward W.

1993 Culture \& Imperialism. London: Chatto \& Windus.

1994 Representations of the Intellectual: The 1993 Reith Lectures. London: Vintage.

Sartre, Jean-Paul

1977 Life/Situations: Essays Written and Spoken. New York: Pantheon Books.

Sassen, Saskia

1994 Cities in a World Economy. London: Pine Forge Press.

Seidman, Steven

1994 Contested Knowledge: Social Theory in the Postmodern Era. Oxford: Blackwell.

Shepperson, Arnold

1998 [Book review of Tomaselli 1996.] Visual Anthropology, 11:267-271.

Shukman, Ann

1988 Bakhtin School Papers. Oxford: RPT Publications.

Soja, Edward

1989 Postmodern Geographies: The Reassertion of Space in Critical Social Theory. London: Verso.

Svitak, Ivan

1970 Man and His World: A Marxian View. Trans. by Jarmila Vettrusky. New York: Delta Books.

Therborn, Goran

1980 Science, Class and Society. New York: Verso.

Tomaselli, Keyan G.

1996 Appropriating Images: The Semiotics of Visual Representation. lfujbjerg: Intervention Press.

1999 State of the Discipline: Communication Studies Commissioned by the National Research Forum. Durban: Graduate Programme in Cultural and Media Studies, University of Natal.

Tomaselli, Keyan, Alan Williams, Lynette Steenveldt, and Ruth Tomaselli

1986 Myth, Race and Power: South Africans Imaged on Film and TV. Bellville: Anthropos Publishers.

University of the Witwatersrand electronic Debate List. 15 March 2000. debate@sunsite. wits.ac.za.

Waugh, Patricia (ed.) 
1992 Postmodernism: A Reader. London: Edward Arnold.

West, Cornell

1982 Prophesy Deliverance! An Afro-American Revolutionary Christianity. Philadelphia: Westminster Press.

1993 Race Matters. Boston: Beacon Press.

Williams, John James

1989 Urban Social Movements in Metropolitan Cape Town, South Africa. Urbana: Unpub- lished Ph.D. Thesis, University of Illinois at Urbana-Champaign.

Wolfe, Marshall

1996 Elusive Development. London: Zed Books.

World Bank

2000 World Bank Study highlights the need for the poor to be empowered. Washington DC: External Affairs Department, World Bank, http://www.worldbank.org/news.

Young, Robert

1995 Colonial Desire: Hybridity in Theory, Culture and Race. London: Routledge. 